\title{
Solitary Eyelid Neurofibroma: Case Report
}

\author{
Wilson Onuigbo IB*, Achebe JU and Ogbonnaya IS \\ Departments of Pathology and Surgery, Nigeria \\ *Corresponding author: Wilson IB Onuigbo, Departments of Pathology and Surgery, Nigeria

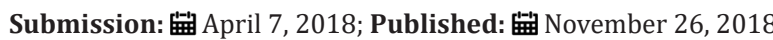

\begin{abstract}
The neurofibroma is better known when it manifests all over the body as neurofibromatosis or von Recklinghausen disease. However, it may be solitary. The eyelid is a choice site with reports from several countries. Therefore, this paper reports a case concerning the Ibo ethnic group in Nigeria.
\end{abstract}

Keywords: Neurofibroma; Neurofibromatosis; Eyelid; Orbit; Nigeria

\section{Introduction}

The Merriam-Webster's Collegiate Dictionary defines "neurofibroma" as "a fibroma composed of nervous and connective tissue" [1]. As it usually renders, 1892 was the earliest year of its use. Since then, emphasis has been on generalized bodily distribution of these lesions. Elsewhere [2], the appearances in infancy and childhood among the Ibo ethnic group were presented personally [3]. Here, this paper compares its odd appearance in the eyelid with reference to comparative examples from India [4-8], Korea $[9,10]$, Taiwan [11] and USA [12].

\section{Case Report}

UB, a 9-year-old girl, was brought to the Children's Ward at the National Orthopaedic Hospital, Enugu, Nigeria, under the care of Dr Achebe and Dr Ogbonnaya. The complaint of her mother was swelling of the child's left upper eyelid from birth. It progressively increased in size. Therefore, incisional biopsy was carried out under the impression of this being due to "Orbitofacial plexifom neurofibromatosis (Type 1)." The specimen was received by the senior author (WIBO). It was a $5 \mathrm{~cm}$ elongated wedge containing the skin, and an underlying tumorous mass. On microscopy, the tumor was benign. The nuclei tended to be wavy. Abortive nerves abounded. Myxomatous change was noted in parts. Accordingly, neurofibromatosis was confirmed.

\section{Discussion}

French authors wrote that neurofibromatosis of the orbitopalpebral complex is a debilitating disease. Their series demonstrated that a tailored often radical palpebral remodelling in orbitopalpehral neurofibromatosis may provide functional and aesthetic benefit. Our case was handled with little difficulty. Age at presentation is interesting. On looking at the Indian series, the range included 19 years [5], 64 years [6] and 53 years [8]. Clearly, our local patient came in early in good time. Indeed, it was only bettered by the 12-year-old Korean patient [9]. From USA, the authors concluded that "Ultimately, orbital exenteration may be needed for rehabilitation and cosmesis" [12]. One Indian patient underwent surgery for the same lesion twice [8]. Our patient has fared better. It may be added that the eyelid neurofibroma may present as a tarsal cyst [6], mimick chalazion [8,11], or simulate optic nerve glioma [9]. In contrast, the local surgeons were able to readily diagnose "Orbital plexiform neurofibromatosis (Type 1)." In Korea, a 34-year-old man, who underwent excision of a neurofibroma on the right eyelid, returned following orbital dystopia which had to be corrected [10]. Our patient's recovery was uneventful..

\section{References}

1. Merriam-Webster's Collegiate Dictionary. Mass, $\left(12^{\text {th }}\right.$ edn), Springfield, Merriam-Webster Inc., Massachusetts, USA, p. 833.

2. Onuigbo WIB (2017) The epidemiology of neurofibroma in infancy and childhood among Nigerian Igbos. J Gen Pract 5: 1.

3. Basden GT (1966) Among the Ibos of Nigeria, 1921. Reprinted Cass, London.

4. Marchac D, Britto JA (2005) Remodelling the upper eyelid in the management of orbitopalpebral neurofibromatosis. Br J Plast Surg 58(7): 944-956.

5. Balasubramanyam M, Cugati G, Mukherjee B (2012) Orbitotemporal neurofibromatosis: Case report. Case Rep Ophthalmol Med, pp. 1-3.

6. Poonam NS, Alam MdS, Das D, Biswas J (2018) Solitary eyelid neurofibroma presenting as tarsal cyst: Report of a case and review of literature. Am J Ophthalmol Case Rep 10: 71-73.

7. Rizvi SAR, Kesarwai D, Maheshwari V, Aziz M (2013) Eyelid plexiform neurofibroma: Atypical presentation and management. Case Rep Int J Ophthalmol Pathol 2(4).

8. Pai HV, Abbagani S, Jaishankar PP (2018) Isolated neurofibroma of the eyelid mimicking recurrent chalazion. Indian J Ophthalmol 66(3): 451453. 
9. Yoon HJ, Yoon KC, Kim GE, Choi W (2017) Solitary pigmented plexiform neurofibroma in lower eyelid: A case report. J Korean Ophthalmol Soc 58(3): 333-336.

10. Choi MSS, Choi SH, Lee JH (2016) Surgical correction in orbitotemporal neurofibromatosis with dystopia. BMC Ophthalmology 16: 4.
11. Chen N, Hsu YH, Lee YC (2017) Solitary neurofibroma of eyelid masquerading as chalazion. Int Med Case Rep J 10:177-179.

12. Erb MH, Uzcategui N, See RF, Burnstine MA (2007) Orbitotemporal neurofibromatosis: Classification and treatment. Orbit 26(4): 223-228. (c) (P) Creative Commons Attribution 4.0

For possible submissions Click Here
Submit Article

\section{MSOR Mercal \& \\ Medical \& Surgical Ophthalmology Research} Ophithalmology
Rescarch

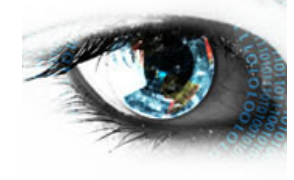

\section{Benefits of Publishing with us}

- High-level peer review and editorial services

- Freely accessible online immediately upon publication

- Authors retain the copyright to their work

- Licensing it under a Creative Commons license

- Visibility through different online platforms 